\title{
Formation and persistence of O6-(2-hydroxyethyl)-2 -deoxyguanosine in DNA of various rat tissues following a single dose of N-nitroso-N-(2-hydroxyethyl)urea. An immuno-slot-blot study
}

\author{
Ludeke, Barbara I ; Kleihues, Paul
}

\begin{abstract}
Rabbit antibodies against O6-(2-hydroxyethyl)-2 -deoxyguanosine (O6-HEdG) were used to develop a highly sensitive immuno-slot-blot assay for this promutagenic base which enabled the quantitation of $3.6 \mathrm{~mol}$ O6-HEdG/mol deoxy-guanosine, corresponding to $5 \mathrm{fmol}$ in a 3 - g DNA sample. This assay was used to study DNA hydroxyethylation by N-nitroso-N-(2-hydroxyethyl)urea (HENU) in adult male F344 rats. Initial amounts of O6-HEdG $2 \mathrm{~h}$ after a single i.v. dose of $50 \mathrm{mg} / \mathrm{kg}$ were highest in kidney (81 mol O6HEdG/mol deoxyguanosine), followed by lung and liver $(67$ and $55 \mathrm{~mol} / \mathrm{mol} \mathrm{dG}$ respectively). Formation of O6-HEdG in cerebral DNA was considerably lower (18 mol O6-HEdG/mol deoxyguanosine), probably reflecting delayed crossing of the blood-brain barrier by HENU due to its hydrophilicity. The formation of O6-HEdG in liver and kidney was strictly proportional to dose over a range of 5-50 mg HENU/kg. Repair of O6-HEdG was very rapid in liver (apparent half-life, $12 \mathrm{~h}$ ), and somewhat slower in kidney and lung (approximate half-life, $40 \mathrm{~h}$ and $48 \mathrm{~h}$ respectively). In contrast, $62 \%$ of the initial amount of O6-HEdG in cerebral DNA was still present after 7 days. Saturation of the hepatic O6-alkyl-guanine-DNA alkyltransferase by pretreatment with N-nitrosodimethylamine (20 $\mathrm{mg} / \mathrm{kg}$ ) almost completely inhibited the removal of $\mathrm{O} 6-\mathrm{HEdG}$, indicating that O6-HEdG is predominantly repaired by this repair enzyme
\end{abstract}

DOI: https://doi.org/10.1093/carcin/9.1.147

Posted at the Zurich Open Repository and Archive, University of Zurich ZORA URL: https://doi.org/10.5167/uzh-154127

Journal Article

Published Version

Originally published at:

Ludeke, Barbara I; Kleihues, Paul (1988). Formation and persistence of O6-(2-hydroxyethyl)-2 -deoxyguanosine in DNA of various rat tissues following a single dose of N-nitroso-N-(2-hydroxyethyl)urea. An immunoslot-blot study. Carcinogenesis, 9(1):147-151.

DOI: https://doi.org/10.1093/carcin/9.1.147 


\section{Formation and persistence of $O^{6}$-(2-hydroxyethyl)-2'-deoxyguanosine in DNA of various rat tissues following a single dose of $N$-nitroso- $N$-(2-hydroxyethyl)urea. An immuno-slot-blot study}

\author{
Barbara I.Ludeke and Paul Kleihues \\ Laboratory of Neuropathology, Institute of Pathology, University of Zurich, \\ CH-8091 Zürich, Switzerland
}

Rabbit antibodies against $O^{6}$-(2-hydroxyethyl)-2'-deoxyguanosine $\left(O^{6}\right.$-HEdG) were used to develop a highly sensitive immuno-slot-blot assay for this promutagenic base which enabled the quantitation of $\geq 3.6 \mu \mathrm{mol} O^{6}-\mathrm{HEdG} / \mathrm{mol}$ deoxyguanosine, corresponding to $\geq 5 \mathrm{fmol}$ in a 3- $\mu$ g DNA sample. This assay was used to study DNA hydroxyethylation by $N$ nitroso- $N$-(2-hydroxyethyl)urea (HENU) in adult male F344 rats. Initial amounts of $\partial^{6}$-HEdG 2 h after a single i.v. dose of $50 \mathrm{mg} / \mathrm{kg}$ were highest in kidney $\left(81 \mu \mathrm{mol} O^{6}-\mathrm{HEdG} / \mathrm{mol}\right.$ deoxyguanosine), followed by lung and liver (67 and 55 $\mu \mathrm{mol} / \mathrm{mol} \mathrm{dG}$ respectively). Formation of $O^{6}$-HEdG in cerebral DNA was considerably lower $\left(18 \mu \mathrm{mol} O^{6}\right.$-HEdG/ mol deoxyguanosine), probably reflecting delayed crossing of the blood-brain barrier by HENU due to its hydrophilicity. The formation of $O^{6}$-HEdG in liver and kidney was strictly proportional to dose over a range of 5-50 mg HENU/kg. Repair of $\boldsymbol{O}^{6}$-HEdG was very rapid in liver (apparent halflife, $12 \mathrm{~h}$ ), and somewhat slower in kidney and lung (approximate half-life, $40 \mathrm{~h}$ and $48 \mathrm{~h}$ respectively). In contrast, $62 \%$ of the initial amount of $O^{6}$-HEdG in cerebral DNA was still present after 7 days. Saturation of the hepatic $O^{6}$-alkylguanine-DNA alkyltransferase by pretreatment with $N$-nitrosodimethylamine $(20 \mathrm{mg} / \mathrm{kg})$ almost completely inhibited the removal of $O^{6}$-HEdG, indicating that $O^{6}$-HEdG is predominantly repaired by this repair enzyme.

\section{Introduction}

During the past decade, chemical DNA modifications by methylating and ethylating carcinogens have been extensively investigated $(1,2)$. DNA hydroxyethylation has attracted much less attention although it is known that a large number of diverse chemicals may yield a hydroxyethylating species as ultimate reactant. $N$-nitroso- $N$-(2-hydroxyethyl)urea (HENU*) has been shown to induce thymic lymphoma in mice at an incidence similar to and a latency period shorter than its ethyl analogue (3), indicating that hydroxyethylation constitutes a powerful initiating DNA lesion. HENU is highly mutagenic in bacteria $(4,5)$. Reports on miscoding in vitro have not been published, but mispairing during DNA replication would be expected to be similar to that caused by ethylated bases $(1,2)$.

Other carcinogenic nitrosoureas known to hydroxyethylate DNA include $N$-nitroso- $N$-(2-hydroxyethyl)- $N^{\prime}$-ethylurea (6) and $N$-nitroso- $N$-(2-hydroxyethyl)- $N^{\prime}$-(2-chloroethyl)urea (7). The

\footnotetext{
'Abbreviations: $O^{6}$-HEdG, $O^{6}$-(2-hydroxyethyl)-2'-deoxyguanosine; HENU, $N$ nitroso- $N$-(2-hydroxyethyl)urea; $O^{6}$-MEdG, $O^{6}$-methyl-2'-deoxyguanosine; MNU, $N$-nitroso- $N$-methylurea; NDMA, $N$-nitrosodimethylamine; PBS, phosphate-buffered saline (140 mM NaCl, $2.7 \mathrm{mM} \mathrm{KCl}, 8.1 \mathrm{mM} \mathrm{Na} \mathrm{HPO}_{4}$, $1.5 \mathrm{mM} \mathrm{KH} \mathrm{KH}_{4}, \mathrm{pH}$ 7.2); PBS-HS, PBS containing an additional $160 \mathrm{mM}$ $\mathrm{NaCl}$.
}

carcinogenicity of therapeutic haloethylnitrosoureas has been attributed to their capacity for DNA hydroxyethylation (8). However, the relative extent of this reaction appears to be significantly lower in vivo than in vitro and occurs through a mechanism not yet fully understood $(9,10)$. Nitrosamines which primarily methylate ( $N$-nitrosomethylethylamine) or ethylate ( $N$-nitrosodiethylamine) DNA have recently been shown to yield hydroxyethylating intermediates by minor metabolic pathways (11). DNA hydroxyethylation has also been proposed for several environmental and industrial pollutants, including $N$-nitrosodiethanolamine, a contaminant of cosmetics, tobacco and synthetic cutting oils, and $N$-nitrosomorpholine, an airborne carcinogen prevalent in the rubber industry $(10,12,13)$. The pioneering work of Segerbäck (14) has provided evidence that ethene and ethylene oxide, chemicals with extensive industrial applications, also produce hydroxyethylated bases in addition to other DNA lesions.

This widespread occurrence of hydroxyethylating agents has prompted us to develop a sensitive assay system for $O^{6}-(2-$ hydroxyethyl)-2'-deoxyguanosine $\left(O^{6}\right.$-HEdG) with potential application to molecular dosimetry in humans exposed to these agents either therapeutically or environmentally. The immunoslot-blot technique described by Nehls $e t$ al. (15) appeared to be particularly useful since it requires very small amounts of DNA.

\section{Materials and methods}

\section{Chemicals}

HENU was provided by Dr W.Lijinsky (NCI, Frederick Cancer Research Facility, Frederick, MD). $O^{6}$-(2-hydroxyethyl)guanosine was a kind gift of Dr W.Lijinsky and Dr G.Eisenbrand (University of Kaiserslautern, FRG). N-Nitrosodimethylamine (NDMA) was obtained from Schuchardt, München, FRG. Calf thymus DNA was purchased from Sigma Chemie, Deisenhofen, FRG. DNA-grade hydroxyapatite was from Boehringer-Mannheim (Schweiz) AG, Rotkreuz, Switzerland. Keyhole limpet hemocyanin was purchased from Calbiochem AG, Luzern, Switzerland. Goat anti-rabbit IgG horseradish peroxidase conjugates were obtained from Nordic Immunology, Tilburg, The Netherlands (Lot 6-686) and from Kirkegaard and Perry Laboratories, Gaithersburg, MD (Lot HL43-5). 4-Chloro-1-naphthol was from Bio-Rad Laboratories AG, Glattbrugg, Switzerland.

\section{Antisera}

$O^{6}$-(2-Hydroxyethyl-2'-deoxyguanosine ( $\sigma^{6}$-HEdG) and $\sigma^{6}$-methyl-2'-deoxyguanosine $\left(O^{6}-\mathrm{MEdG}\right)$ were coupled to keyhole limpet hemocyanin (16). Rabbits were immunized by i.m. injections of the respective nucleoside conjugate (1 mg/animal), emulsified 1:1 with Freund's complete adjuvant. Animals were boosted 8,16 and 18 weeks later with the same amount of antigen in Freund's incomplete adjuvant. Antisera were collected 2 weeks later.

\section{Alkylated DNA standards}

Hydroxyethylated and methylated DNA standards were prepared by reacting calf thymus DNA (dissolved in $80 \mathrm{mM}$ Tris, pH $8.0,2.2 \mathrm{mg} / \mathrm{ml}$ ) with HENU or $N$-nitroso- $N$-methylurea (MNU), at a final concentration of $5.5 \mathrm{mg} / \mathrm{ml}$. The alkylation reaction was allowed to proceed at $37^{\circ} \mathrm{C}$ for $30 \mathrm{~min}$. The DNA was precipitated with 2-ethoxyethanol and washed twice in absolute ethanol and ether. The concentration of $O^{6}$-alkylguanines was determined by HPLC with fluorescence detection as described earlier (17) except that $50 \mathrm{mM} \mathrm{NH}_{4} \mathrm{H}_{2} \mathrm{PO}_{4}$ (pH 2.0 ) containing $3 \%$ methanol was used to elute $O^{6}$-(2-hydroxyethyl)guanine.

Animal experiments

Young male Fischer 344 rats (Charles River Wiga GmbH, Sulzfeld, FRG; $120 \mathrm{~g}$ average body wt) received i.v. injections of HENU (dissolved in $3 \mathrm{mM}$ sodium citrate buffer, $\mathrm{pH} \mathrm{6.0)}$ ) at doses ranging from 5 to $50 \mathrm{mg} / \mathrm{kg}$ body wt (see figure 
legends). Two rats were injected for each set of conditions. In one experiment, the animals received an i.p. injection of $20 \mathrm{mg} / \mathrm{kg}$ NDMA, followed $3 \mathrm{~h}$ later by i.v. administration of $50 \mathrm{mg} / \mathrm{kg}$ HENU. Rats were killed by exsanguination under ether anesthesia and the organs pooled and quickly frozen in liquid nutrogen. DNA isolation

DNA was purified by phenol extraction and adsorption onto hydroxyapatite as previously described (18). The DNA was dissolved in $10 \mathrm{mM}$ Tris, pH 7.8, containing $1 \mathrm{mM}$ EDTA and quantitated by reaction with diphenylamine (19) using standard curves generated with unmodified calf thymus DNA.

Immuno-slot-blots

Immuno-slot-blots were carried out essentially as described by Nehls et al. (15). Briefly, DNA samples $9 \mu \mathrm{g}$ in $300 \mu \mathrm{l}$ ) were heat-denatured for $10 \mathrm{~min}$ in a boiling water bath, quickly chilled on ice, and mixed with an equal volume of $2 \mathrm{M}$ ammonium acetate. Single-stranded DNA was then immobilized on nitrocellulose filters (BA 52, Schleicher and Schüll, Feldbach, Switzerland) using a Minifold II microfiltration apparatus (Schleicher and Schüll). Filters were presoaked in $1 \mathrm{M}$ ammonium acetate. After application of $200 \mu$ l containing $3 \mu \mathrm{g}$ DNA, the slots were rinsed with $200 \mu \mathrm{l} 1 \mathrm{M}$ ammonium acetate. The filters were then removed from the support, soaked in $0.75 \mathrm{M} \mathrm{NaCl}$ and $0.075 \mathrm{M}$ trisodium citrate for $5 \mathrm{~min}$, blow-dried and baked at $80^{\circ} \mathrm{C}$ for $2.5 \mathrm{~h}$. After treatment for $30 \mathrm{~min}$ at $37^{\circ} \mathrm{C}$ with $0.5 \%$ casein in phosphate-buffered saline (PBS) to block non-specific protein-binding sites, the filters were incubated overnight at $4^{\circ} \mathrm{C}$ with the appropriate rabbit antiserum diluted 1:4000 (anti- $O^{6}-\mathrm{MEdG}$ ) or 1:15000 (anti- $O^{6}$ HEdG) in the same casein buffer. The filters were subsequently washed three times in casein buffer, once in high saline PBS (PBS-HS), and once in PBS-HS containing $0.1 \%$ Triton $X-100$, allowing $10 \mathrm{~min}$ for each buffer change. The last two steps were repeated once. Following a final wash in PBS, the bound antibodies were reacted with goat anti-rabbit IgG horseradish peroxidase conjugate, diluted 1:1000 (Nordic) or 1:2500 (Kirkegaard and Perry) in PBS containing $0.5 \%$ casein. The incubation was carried out for $3 \mathrm{~h}$ at room temperature. The nitrocellulose strips were then washed as above. Enzymatic activity was visualized by incubation in a solution of $2 \mathrm{mg} / \mathrm{ml}$ 4-chloro-1-naphthol and $0.015 \%$ hydrogen peroxide in $20 \mathrm{mM}$ Tris, pH 7.5 and $500 \mathrm{mM} \mathrm{NaCl}$ for $20 \mathrm{~min}$ at $35^{\circ} \mathrm{C}$. The blots were subsequently rinsed extensively with distilled water and stored wet in the dark at $4^{\circ} \mathrm{C}$.

Densitometry

Densitometric evaluation was performed using a Shimadzu Model CS-930 dualwavelength thin-layer chromatogram scanner in the zig-zag mode at $590 \mathrm{~nm}$. Peak heights were measured manually. Standard curves were constructed by plotting peak heights after subtraction of background binding to unmodified DNA in a double log plot. Curve fitting was carried out by quadratıc regression analysis (Figure 1).

\section{Results}

A typical immuno-slot-blot calibration curve for $O^{6}$-HEdG in heat-denatured DNA is shown in Figure 1. The peak heights obtained by densitometric evaluation of the colored blots are plotted against the $O^{6}$-HEdG content in the respective slots after subtraction of the value for background binding to unmodified DNA. As can be seen from the diagram, $\geq 1.4 \mathrm{fmol}{ }^{6}$-HEdG can still be detected in a total amount of $3 \mu \mathrm{g}$ DNA. This corresponds to $0.9 \mu \mathrm{mol} O^{6}-\mathrm{HEdG} / \mathrm{mol}$ deoxyguanosine. However, we set the lower limit for quantitative determination at $3.6 \mu \mathrm{mol}$ $O^{6}$-HEdG/mol deoxyguanosine. Sensitivity of the immuno-slotblot technique for the determination of $O^{6}-\mathrm{MEdG}$ was similar, with a detection limit of at least $2.8 \mathrm{fmol} O^{6}-\mathrm{MEdG}$ in $3 \mu \mathrm{g}$ DNA, corresponding to $1.8 \mu \mathrm{mol} O^{6}-\mathrm{MEdG} / \mathrm{mol}$ deoxyguanosine. Anti- $O^{6}$-HEdG serum (NPZ 146-2) showed crossreactivity with $O^{6}$-MEdG (Figure 2 ); the difference in concentration required for obtaining identical peak heights was - 30-fold. Conversely, anti-O6-MEdG serum (NPZ 193-1) showed no reactivity with hydroxyethylated DNA (not shown).

The persistence of $O^{6}$-HEdG in DNA of various rat organs following a single i.v. dose of $50 \mathrm{mg} \mathrm{HENU} / \mathrm{kg}$ is shown in Figure 3. Initial amounts of $O^{6}-\mathrm{HEdG}$ were similar in DNA of kidney and lung. Slightly lower levels of this modified base were observed in liver DNA. However, the loss of $O^{6}$-HEdG from hepatic DNA was faster than from DNA of other organs, the half-life being $\sim 12 \mathrm{~h}$. The rate of removal of this modified base

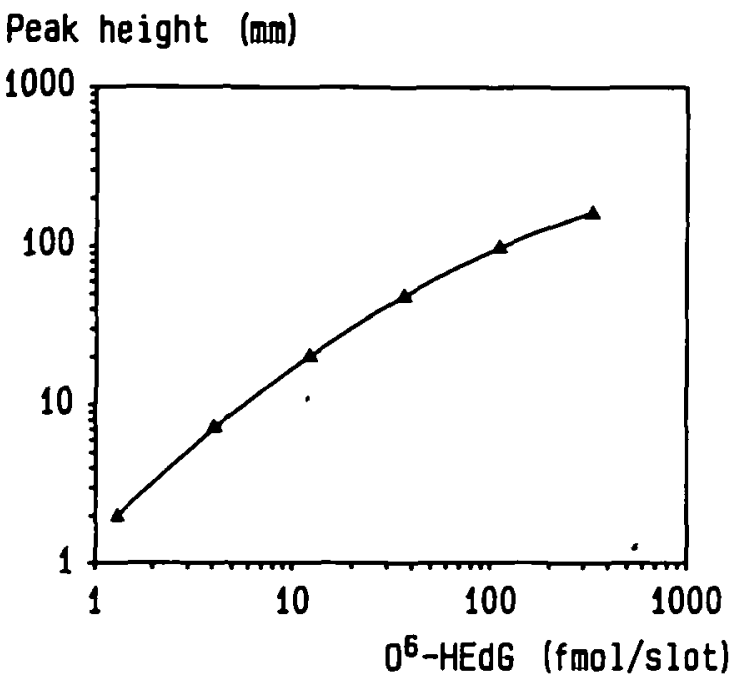

Fzg. 1. Typical calibration curve for the determination of $\sigma^{6}$-HEdG. DNA $(3 \mu \mathrm{g})$ containing $O^{6}-\mathrm{HEdG}(1.3-328 \mathrm{fmol})$ was blotted onto nitrocellulose. After incubation with rabbit anti- $O^{6}$-HEdG serum, bound antibodies were reacted with a goat anti-rabbit IgG horseradish peroxidase conjugate. Enzymatic activity was measured via color development as described in the text. Peak height values are plotted against the respective amounts of $O^{6}$-HEdG after subtraction of the value for non-specific binding to $3 \mu \mathrm{g}$ unmodified DNA.

\section{Peak height (mm)}

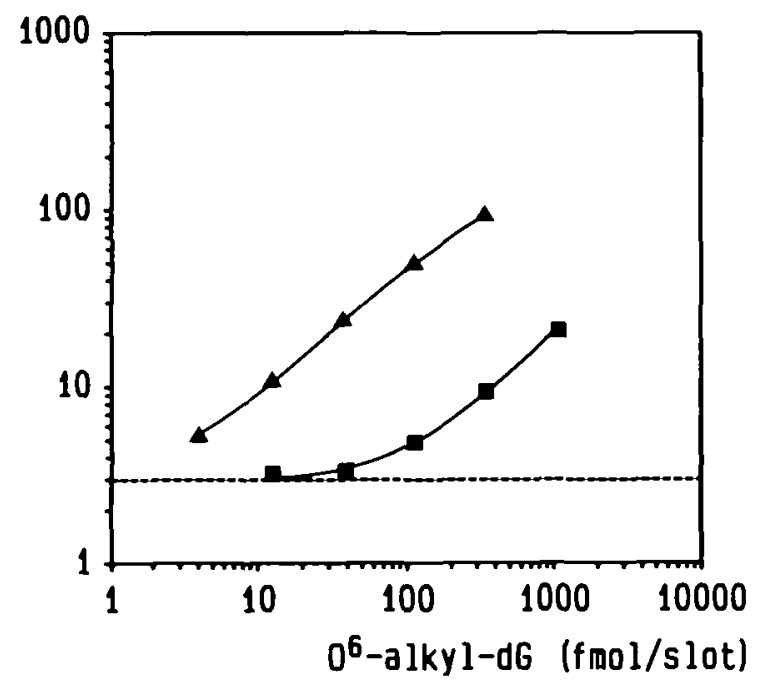

Fig. 2. Reactivity of rabbit anti- $O^{6}$-HEdG serum with hydroxyethylated and methylated DNA. In a double logarithmic plot, the peak heights are plotted aganst the respective amounts of $\sigma^{6}-\mathrm{HEdG}(\Delta)$ and $\sigma^{6}-\mathrm{MEdG}(\boldsymbol{D})$ applied to each slot. The dashed line represents the value for non-specific binding of the antisenm to nonalkylated DNA.

from kidney and lung DNA was similar, with an apparent halflife of 40 and $48 \mathrm{~h}$ respectively. In contrast, $O^{6}$-HEdG concentrations in brain DNA was initially lower (35\% of that in liver) but persisted longer than in any other tissue investigated. The 7-day values, when expressed as a fraction of the initial $(2-\mathrm{h})$ $O^{6}$-HEdG concentration, ranged from $4.7 \%$ (liver), $23.5 \%$ (kidney), 25.7\% (lung) to 62.4\% (brain). The dose-dependent formation of $O^{6}$-HEdG was studied in liver and kidney. The regression lines obtained (Figure 4) had slopes close to 1 , indicating that this promutagenic base is formed strictly proportional to dose over the entire dose range investigated. The regression equations as calculated by the least-squares method 


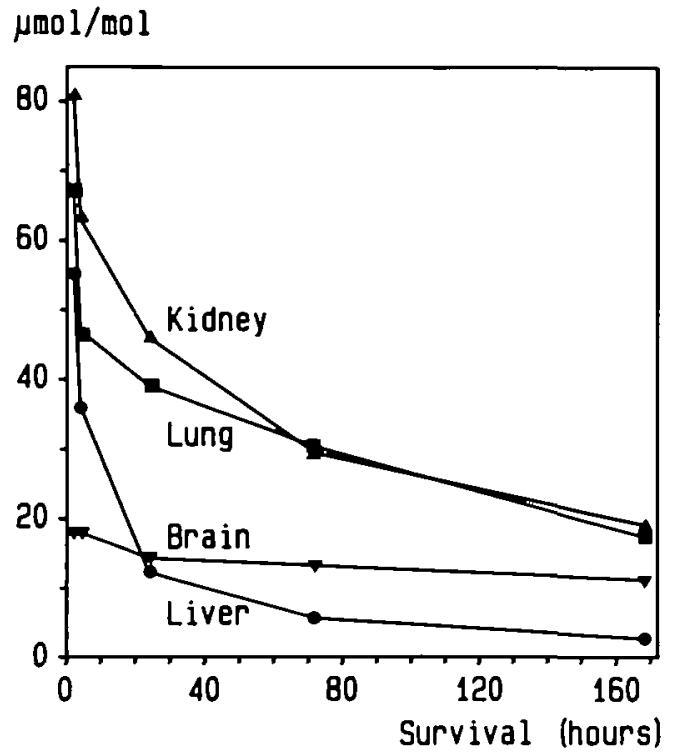

Fig. 3. Persistence of $O^{6}$-HEdG in DNA of various rat tissues following a single i.v. dose of $50 \mathrm{mg} / \mathrm{kg}$ HENU and survival times ranging from $2 \mathrm{~h}$ to 7 days. Results are expressed as $\mu \mathrm{mol} / \mathrm{mol}$ deoxyguanosine.

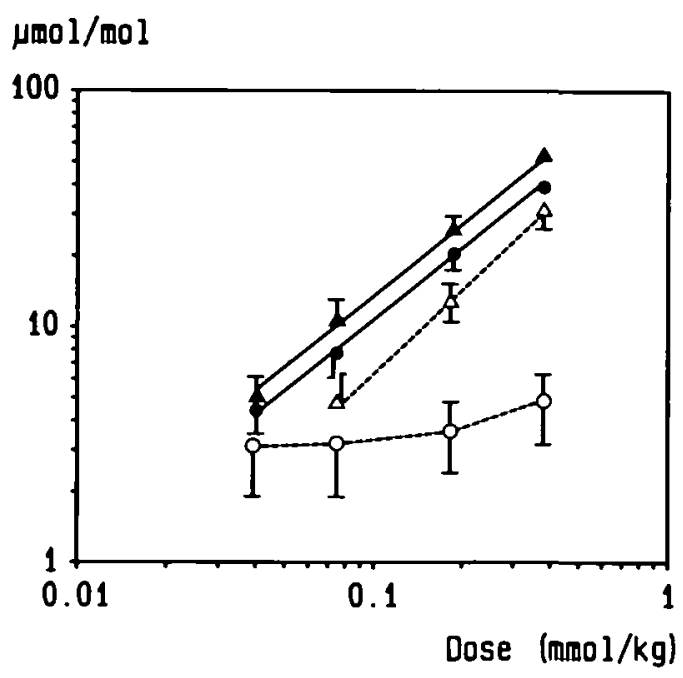

Fig. 4. Dose-dependent formation and concentration-dependent repair of $O^{6}$-HEdG in liver $(\bullet, O)$ and kidney $(\Delta, \Delta)$ DNA. Rats were killed $4 \mathrm{~h}$ (closed symbols, solid lines) and 3 days (open symbols, dashed lines) after a single i.v. dose of HENU ranging from 0.039 to $0.38 \mathrm{mmol} / \mathrm{kg}$, corresponding to 5 to $50 \mathrm{mg} / \mathrm{kg}$. Data represent mean \pm SEM of 4-6 determinations.

were:

$$
\begin{aligned}
& \log O^{6} \text {-HEdG }=1.01 \times \log \text { dose }+2.04 \quad \text { liver } \\
& \log O^{6} \text {-HEdG }=1.01 \times \log \text { dose }+2.14 \text { kidney }
\end{aligned}
$$

In animals allowed to survive for 3 days after a single dose of HENU, the amounts of $O^{6}$-HEdG in kidney DNA were generally lower and the slope of the regression line was steeper than after $4 \mathrm{~h}$, indicating that disproportionately more $O^{6}$-HEdG had been removed from DNA of animals exposed to lower doses of HENU. The regression line was:

$$
\log O^{6}-\mathrm{HEdG}=1.18 \times \log \text { dose }+1.98 \text { kidney }
$$

In liver DNA, most of the $O^{6}$-HEdG initially formed had been removed and a clear dose dependency was no longer evident after 3 days. However, at each of the doses administered, a small

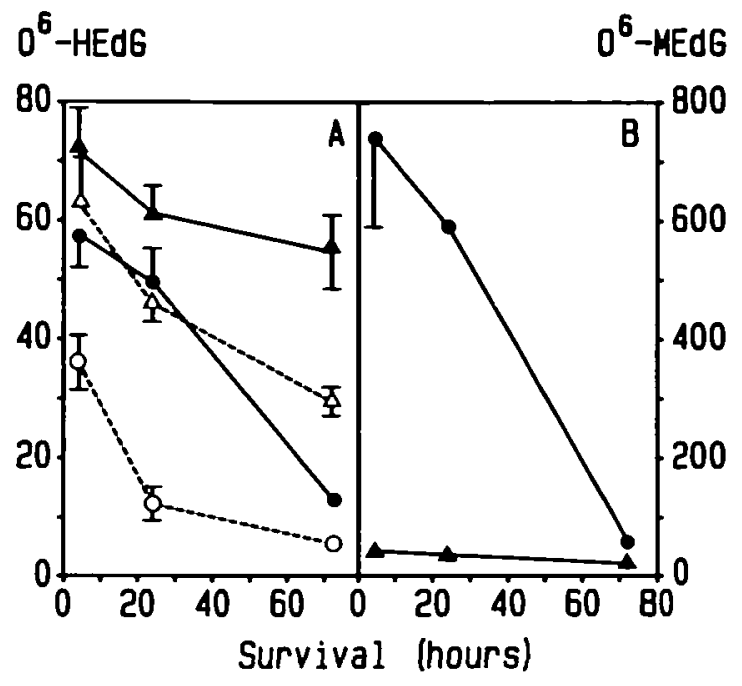

Fig. 5. (A) Persistence of $O^{6}$-HEdG in liver and kidney DNA after saturation of the $O^{6}$-alkylguanıne-DNA alkyltransferase with medG. Rats received i.p. injections of $20 \mathrm{mg} / \mathrm{kg}$ NDMA and, $3 \mathrm{~h}$ later, a chasing i.v. dose of $50 \mathrm{mg}$ HENU per $\mathrm{kg}$. After survival times of $4 \mathrm{~h}, 24 \mathrm{~h}$ and 3 days, $O^{6}$-HEdG was determined by immuno-slot-blot analysis after correction for cross-reactivity of the anti- $O^{6}$-HEdG serum with $O^{6}$-MEdG (closed symbols, solid lines). For comparison, the persistence of $O^{6}$-HEdG without pretreatment with NDMA is also shown (open symbols, dashed lines, data taken from Figure 3). Liver $(\bullet, O)$; kidney $(\Delta, \triangle)$. The amounts of $O^{6}$-alkylguanines are expressed as $\mu \mathrm{mol} / \mathrm{mol}$ deoxyguanosine.

amount of $O^{6}$-HEdG was found to persist $(\sim 3-5 \mu \mathrm{mol} / \mathrm{mol}$ $d G)$.

To test whether the removal of $O^{6}$-HEdG competes with that of other $O^{6}$-alkylguanines, an additional experiment was carried out in which animals were pretreated with $20 \mathrm{mg} / \mathrm{kg}$ of NDMA, i.e. a dose known to produce saturating levels of $O^{6}$-MEdG in rat liver DNA. As shown in Figure 5, this almost completely inhibited the repair of $O^{6}$-HEdG in hepatic DNA during the first $24 \mathrm{~h}$ following HENU application. Although the amount of $O^{6}$-MEdG in kidney was $\sim 19$ times lower than in liver, this still resulted in a significant inhibition of the repair of $O^{6}$-HEdG produced by a subsequent dose of HENU.

\section{Discussion}

The sensitivity of the immuno-slot-blot assay for $O^{6}$-HEdG was found to be similar to that achieved by Nehls et al. (15) for $O^{6}$-ethyldeoxyguanosine and $O^{4}$-ethyldeoxythymidine. These authors employed murine monoclonal antibodies but we found the use of rabbit antisera not to be disadvantageous. Significant cross-reactivity was only observed for the reaction of the anti$O^{6}$-HEdG serum with methylated DNA, whereas the anti- $O^{6}$ MEdG serum did not recognize $O^{6}$-HEdG. Even the simultaneous presence of excess amounts of $O^{6}$-MEdG in hepatic DNA did not interfere with the quantitation of 10-fold lower levels of $O^{6}$-HEdG (Figure 5). In preliminary experiments we used an alkaline phosphatase-conjugated second antibody for quantitative evaluation. However, we found that the colored precipitate resulting from the reaction of 4-chloro-1-naphthol with horseradish peroxidase yielded a superior signal-to-noise ratio. Since the intensity of the color reaction showed day-to-day variations, we found it mandatory to include a complete set of standards on each blot. In its present form, the assay enables the quantitation of $\geq 5 \mathrm{fmol} \partial^{6}$-HEdG/3 $\mu \mathrm{g}$ DNA, corresponding to $3.6 \mu \mathrm{mol} O^{6}$-HEdG/mol deoxyguanosine. Bio-monitoring in human individuals environmentally exposed to hydroxyethylat- 
ing agents may require greater sensitivity and we are currently investigating experimental modifications yielding a quantifiable signal at lower levels of DNA alkylation.

To test this assay under in vivo conditions, we chose HENU as a model compound since it yields hydroxyethyldiazonium hydroxide as the only alkylating intermediate. As its decomposition is base catalyzed (20) and does not require enzymic bioactivation, one would expect little organ variability in levels of DNA alkylation, as has been shown previously for MNU (21) and $N$-nitroso- $N$-ethylurea (22). Following a single i.v. injection of $50 \mathrm{mg} \mathrm{HENU} / \mathrm{kg}$, the initial (2-h) concentrations of $O^{6}$ HEdG were indeed similar in liver, kidney and lung. The extent of $O^{6}$-hydroxyethylation of guanine in liver and kidney was determined as a function of dose. It was found that in both tissues DNA hydroxyethylation was strictly proportional to amount of HENU administered over the entire dose range (Figure 4). At all doses the kidney values were $29 \%$ higher than those in liver. This could be due to the fact that hydrophilic nitrosoureas such as HENU are, to some extent, excreted via the urine and may thus temporarily accumulate in the kidney. In contrast to its methyl and ethyl analogues, HENU produced a low initial extent of DNA hydroxyethylation in cerebral DNA. This is probably due to its lower lipophilicity. The highly impermeable tight junctions between the cells of the specialized capillary endothelium of the central nervous system which form the morphological basis of the blood-brain barrier largely prevent low mol. wt hydrophilic compounds from entering the brain parenchyma by passive diffusion $(23,24)$.

The persistence of $O^{6}$-HEdG varied considerably among the tissues investigated. The rate of removal was highest in liver. Animals surviving for 7 days had $O^{6}$-HEdG concentrations amounting to $4.7 \%$ of those observed in animals sacrificed $2 \mathrm{~h}$ after a single dose of $50 \mathrm{mg}$ HENU/ $/ \mathrm{kg}$ body wt. The steep decline in $O^{6}$-HEdG levels between 2 and $4 \mathrm{~h}$ (Figure 3) strongly suggests that even the 2 -h value $\left(55 \mu \mathrm{mol} O^{6}\right.$-HEdG/mol deoxyguanosine) does not truly reflect the initial extent of DNA hydroxyethylation. Rapid removal of $O^{6}$-HEdG from hepatic DNA was also documented by the dramatic change in the dose-response curve (Figure 4). Largely irrespective of the initial dose, the 72-h values were reduced to a basal level of 3-6 $\mu \mathrm{mol} O^{6}$-HEdG/mol deoxyguanosine. This low level probably represents persistence in non-parenchymal cells with a low repair capacity $(25,26)$.

The rate of loss of $O^{6}$-HEdG from lung and kidney DNA was somewhat lower than in liver, whereas in cerebral DNA there was significantly less reduction in $O^{6}$-HEdG concentrations. These organ-specific differences closely parallel the activity of the mammalian $O^{6}$-alkylguanine-DNA alkyltransferase in various rat tissues (27). Similar rates of repair were previously observed for $O^{6}$-MEdG (28) and $O^{6}$-ethyldeoxyguanosine (29). $O^{6}$-HEdG is known to be a substrate for $O^{6}$-alkylguanine-DNA alkyltransferase (30) but its rapid removal from rat liver DNA is somewhat surprising since in vitro it is repaired at least 30 times more slowly than $O^{6}$-MEdG and at least 10 times more slowly than $O^{6}$-ethyldeoxyguanosine (31). One reason for this discrepancy could be that a glycosylase with high affinity for $O^{6}$-HEdG exists. It has been suggested that long-chain $O^{6}$-alkylguanines may be repaired by both the $O^{6}$-alkylguanine-DNA alkyltransferase (31) and glycosylase-mediated excision (32). To test this hypothesis, we have carried out an additional experiment based on the observation that the mammalian $O^{6}$-alkylguanine-DNA alkyltransferase stoichiometrically transfers the alkyl group onto one of its own cysteine residues, thereby becom- ing inactivated (33). When the available transferase molecules have been consumed, de novo synthesis is required to restore activity, a process which in vivo requires several days (34). Pretreatment with $20 \mathrm{mg}$ NDMA $/ \mathrm{kg}$ produced $750 \mu \mathrm{mol} O^{6}$ MEdG/mol deoxyguanosine in hepatic DNA, which is in close agreement with the value of $36.7 \mu \mathrm{mol} O^{6}-\mathrm{MEdG} / \mathrm{mol}$ deoxyguanosine/mg NDMA/kg body wt reported earlier (35). Saturation of the hepatic alkyltransferase system in rats occurs at concentrations above $180 \mu \mathrm{mol} O^{6}$-MEdG/mol deoxyguanosine (35). One would, therefore, expect that alkyltransferase-mediated removal of the $O^{6}$-HEdG produced by a subsequent dose of HENU would be significantly inhibited. This was indeed the case (Figure 5A). During the first $24 \mathrm{~h}$ the repair of $O^{6}$-HEdG in liver was almost completely blocked. A similar, albeit less marked, effect was observed in rat kidney even though pretreatment with NDMA produced $O^{6}$-MEdG levels 19 times lower than in liver. These findings strongly suggest that the repair of $O^{6}$ HEdG is indeed predominantly mediated by mammalian $O^{6}$ alkylguanine-DNA alkyltransferase. This corroborates the observation that the mutagenicity of HENU in Escherichia coli does not correlate with the capacity for excision repair (4). The discrepancy between the rapid repair in vivo and the low rate of removal by rat liver extracts in vitro is difficult to explain and poses the question to which extent studies in cell-free systems truly reflect in vivo repair capacity.

Although on the basis of chronic bioassay studies HENU must be regarded as a powerful carcinogen in rats $(6,7,36,37)$, mice (3) and hamsters (38), its target specificity differs from that of its methyl and ethyl analogs. Methyl- and ethylnitrosourea produce a high incidence of tumors of the central and peripheral nervous system following a single perinatal exposure or multiple doses in adult rats (39). In contrast, chronic administration of HENU to F-344 rats led to the development of neural tumors in $<15 \%$ of experimental animals (37). This reduced neurocarcinogenicity may be due to the 3- to 4-fold lower extent of cerebral DNA hydroxyethylation observed in the present study (Figure 3). However, due to the low rate of repair in the nervous system, one would expect long-term accumulation of $O^{6}$-HEdG to levels higher than those in liver and other tissues $(40,41)$. The low incidence of neural tumors produced by HENU in rats may be due to the presence of other target cell populations which undergo malignant transformation more rapidly, e.g. lung and colon (38).

In conclusion, the immuno-slot-blot assay for $O^{6}$-HEdG is highly sensitive, does not require radiolabeled isotopes and allows rapid and reliable quantitation of this promutagenic base under in vivo conditions. It should be particularly useful in establishing a molecular dosimetry during long-term exposure to hydroxyethylating nitrosamines and therapeutic agents.

\section{Acknowledgements}

We thank Mrs I.Cacket for expert technical assistance. This work was supported by the Swiss National Fund and the Cancer League of the Canton of Zürich.

\section{References}

1. Safthill,R., Margison,G.P. and O'Connor,P.J. (1985) Mechanisms of carcinogenesis induced by alkylating agents. Bioctim. Biophys. Acta, 823, $111-145$.

2. Singer, B. and Grunberger,D. (1983) Molecular Biology of Mutagens and Carcinogens. Plenum Press, New York.

3. Swenson,D.H., Frei,J.V. and Lawley,P.D. (1979) Synthesis of 1-(2-hydroxyethyl)-1-nitrosourea and comparison of its carcinogenicity with that of 1-ethyl-1-nitrosourea. J. Natl. Cancer Inst, 63, 1469-1473.

4. Kohda,K.H., Ninorniya,S., Washizu,K., Shiraki,K., Ebie,M. and Kawazoe,Y. (1987) Mutagenicity of a series of $N$-alkyl-, $N$-hydroxyalkyl-, $N$-haloalkyl- 
and $N$-carboxyalkyl- $N$-nitrosoureas in Escherichia coli tester strains: dependence on the uvrA DNA-repair system. Mutar. Res., 177, 219-228.

5. Lijinsky, W., Elespuru, R.K. and Andrews, A.W. (1987) Relative mutagenic and prophage-inducing effocts of mono- and di-alkyl nitrosoureas. Mutat. Res., $178,157-165$

6. Lijinsky,W., Singer,G.M. and Kovatch,R.M. (1985) Similar carcinogenic effects in rats of 1-ethyl-1-nitroso-3-hydroxyethylurea and 1-hydroxyeahyl1-nitroso-3-ethylurea. Carcinogenesis, 6, 641-643.

7. Lijinsky, W., Kovatch, R.M. and Singer,S.S. (1986) Carcinogenesis in F-344 rats induced by nitrosohydroxyalkyl-chloroethylureas. J. Cancer Res. Clin. Oncol., 112, 221-228.

8. Tong, W.P., Kirk,M.C. and Ludlum,D.B. (1981) Molecular pharmacology of the haloethyl nitrosoureas: formation of 6-hydroxyethylguanine in DNA treated with BCNU ( $N, N^{\prime}$-bis[2-chloroethyl]-N-nitrosourea). Biochem. Biophys. Res. Commun., 100, 351-357.

9. Lown,J.W. and Chauhan,S.M.S. (1981) Mechanism of action of (2-haloethyl)-nitrosoureas on DNA. Isolation and reactions of postulated 2-(alkylimino)-3-nitrosooxazolidine intermediates in the decomposition of 1,3-bis(2-chloroethyl)-, 1-(2-chloroethyl)-3-cyclohexyl-, and 1-(2-chloroethyl)-3(4'-transmethylcyclohexyl)-1-nitrosourea. J. Med. Chem., 24, 270-279.

10. Eisenbrand,G., Müller,N., Denkel,E. and Sterzel,W. (1986) DNA adducts and DNA damage by antineoplastic and carcinogenic $N$-nitrosocompounds. J. Cancer Res. Clin. Oncol., 112, 196-204.

11. von Hofe,E., Kleihues,P. and Keefer,L.K. (1986) Extent of DNA 2-hydroxyethylation by $N$-nitrosomethylethylamine and $N$-nitrosodiethylamine in viw. Carcinogenesis, 7, 1335-1337.

12. Preussmann, R. and Stewart,B.W. (1984) $N$-Nitroso carcinogens. In Searle,C.E. (ed.), Chemical Carcinogens, Vol. 2, ACS Monograph 182. American Chemical Society, Washington, DC, pp. 643-828.

13. Sabadie,N., Malaveille,C., Camus,A.-M. and Bartsch,H. (1980) Comparison of the hydroxylation of benzola $a$ pyrene with the metabolism of vinyl chloride, $N$-nitrosomorpholine, and $N$-nitroso- $N^{\prime}$-methylpiperazine to mutagens by human and rat liver microsomal fractions. Cancer Res., 40, 119-126.

14. Segerbäck,D. (1983) Alkylation of DNA and hemoglobin in the mouse following exposure to ethene and ethene oxide. Chem.-Biol. Interactions, 45, $139-151$.

15. Nehls,P., Adamkiewicz,J. and Rajewsky,M.F. (1984) Immuno-slot-blot: a highly sensitive immunoassay for the quantitation of carcinogen-modified nucleosides in DNA. J. Cancer Res. Clin. Oncol., 108, 23-29.

16. Müller, R. and Rajewsky,M.F. (1980) Immunological quantification by high affinity antubodies of $O^{6}$-ethyldeoxyguanosine in DNA exposed to $N$-ethyl$N$-nitrosourea. Cancer Res., 40, 887-896.

17. von Hofe,E. and Kleihues,P. (1986) Comparative studies on hepatic DNA alkylation in rats by $N$-nitrosomethylethylamine and $N$-nitrosodimethylamine plus $N$-nitrosodiethylamine. J. Cancer Res. Clin. Oncol, , 112, 205-209.

18. von Hofe,E., Grahmann,F., Keefer,L.K., Lijinsky,W., Nelson,V. and Kleihues,P. (1986) Methylation versus ethylation of DNA in target and nontarget tissues of Fischer 344 rats treated with $\mathrm{N}$-nitrosomethylethylamine. Cancer Res., 46, 1038-1042.

19. Burton, K. (1956) A study of the conditions and mechanism of the diphenylamine reaction for the colorimetric estimation of deoxyribonucleic acid. Biochem. J., 62, 315-323.

20. Singer,S.S. (1984) Decomposition of $N$-nitrosohydroxyalkylureas and $N$ nitrosooxazolidones in aqueous buffer. LARC Scient. Pub., 57, 371-375.

21. Kleihues,P. and Magee,P.N. (1973) Alkylation of rat brain nucleic acids by $N$-methyl- $N$-nitrosourea and methyl methanesulfonate. $J$. Neurochem., 20, 595-606.

22. Goth,R. and Rajewsky,M.F. (1972) Ethylation of mucleic acids by ethylnitrosourea- $-1{ }^{14} \mathrm{C}$ in the fetal and adult rat. Cancer Res., 32, 1501-1505.

23. Brightman, M.W. and Reese,T.S. (1969) Junctions between intimately apposed cell membranes in the vertebrate brain. J. Cell Bioh, 40, 648-677.

24. Crone,C. (1963) The permeability of capillaries in various organs as determined by use of the 'indicator diffusion' method. Acza Physiol. Scand., 58, $292-305$.

25. Lewis,J.G. and Swenberg,J.A. (1980) Differential repair of $O^{6}$-methylguanine in DNA of rat hepatocytes and nonparenchymal cells. Nature, 288, $185-187$.

26. Menkveld,G.J., Van Der Laken,C.J., Hermsen, T., Kriek,E., Scherer,E. and Den Engelse,L. (1985) Immunohistochemical localization of $O^{6}$-ethyldeoxyguanosine and deoxyguanosin-8-yl-(acetyl)aminofluorene in liver sections of rats treated with diethylnitrosamine, ethylnitrosourea or $\mathrm{N}$-acetylammofluorene. Carcinogenesis, 6, 263-270.

27. Pegg,A.E., Dolan,M.E., Scicchitano,D. and Monmoto,K. (1985) Studies of the repair of $O^{6}$-alkylguanine and $O^{4}$-alkylthymine in DNA by alkyltransferases from mammalian cells and bacteria. Environ. Health Perspect., 62, $109-114$.

28. Kkeihues,P. and Bücheler,J. (1977) Long-term persistence of $O^{6}$-methyl- guanine in rat brain DNA. Nature, 269, 625-626

29. Goth,R. and Rajewsky,M.F. (1974) Molecular and cellular mechanisms associated with pulse-carcinogenesis in the rat nervous system by echylnitrosourea: ethylation of nucleic acids and elimination rates of ethylated bases from the DNA of different tissues. Z Krebsforsch., 82, 37-64.

30. Pegg,A.E., Scicchitano,D. and Dolan,M.E. (1984) Comparison of the rates of repair of $\sigma^{6}$-alkylguanines in DNA by rat liver and bacterial $\phi^{6}$-alkylguanine-DNA alkyltransferase. Cancer Res., 44, 3806-3811.

31. Morimoto,K., Dolan,M.E., Scicchitano,D. and Pegg,A.E. (1985) Repair of $\sigma^{6}$-propylguanine and $\sigma^{6}$-butylguanine in DNA by $\sigma^{6}$-alkylguanine-DNA alkyltransferases from rat liver and E.coli. Carcinogenesis, 6, 1027-1031.

32. Boyle,J.M., Margison,G.P. and Saffhill,R. (1986) Evidence for the excision repair of $O^{6}$-n-butyldeoxyguanosine in human cells. Carcinogenesis, 7 , $1987-1990$

33. Pegg,A.E., Wiest,L., Foote,R.S., Mitra,S. and Perry, W. (1983) Purification and properties of $O^{6}$-methylguanine-DNA transmethylase from rat liver. J. Biol. Chem, 258, 2327-2333.

34. Kleihues,P. and Margison,G.P. (1976) Exhaustion and recovery of repair excision of $O^{6}$-methylguanine from rat liver DNA. Narure, 259, 153-155.

35. Pegg,A.E. and Hui,G. (1978) Formation and subsequent removal of $\partial^{6}$. methylguanine from DNA in rat liver and kidney after small doses of dimethylnitrosamine. Biocthem. J., 173, 739-748.

36. Lijinsky, W. and Reuber,M.D. (1983) Carcinogenicity of hydroxylated alkylnitrosoureas and of nitrosooxazolidones by mouse skin painting and by gavage in rats. Cancer Res., 43, 214-221.

37. Lijınsky,W. and Kovatch,R.M., (1987) Carcinogenesis by nitrosohydroxyethylurea and nitrosomethoxyethylurea in F344 rats. J. Cancer Res. Clin. Oncol., in press.

38. Lijinksy,W. (1984) Species differences in nitrosamine carcinogenesis. $J$. Cancer Res. Clin. Oncol., 108, 46-55.

39. Kleihues,P., Lantos,P.L. and Magee,P.N. (1976) Chemical carcinogenesis in the nervous system. Int. Rev. Exp. Pathol., 15, 153-232.

40. Margison,G.P. and Kleihues,P. (1975) Chemical carcinogenesis in the nervous system. Preferential accumulation of $O^{6}$-methylguanine in rat brain deoxyribomucleic acid during repetitive administration of $N$-methyl- $N$-nitrosourea. Biochem. J., 148, 521-525.

41. Cooper,H.K., Hauenstein,E., Kolar,G.F. and Kleihues,P. (1978) DNA alkylation and neuro-oncogenesis by 3,3-dimethyl-1-phenyltriazene. Acra Neuropathol., 43, 105-109.

Received on August 5, 1987; revised on October 8. 1987; accepted on October 15,1987 